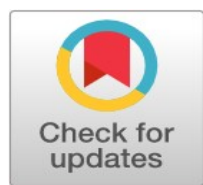

\title{
Investigating corporate social responsibility disclosure by banks from institutional theory perspective
}

\author{
Iman M Arafa Mohamed ${ }^{1}$, Wafaa Salah ${ }^{2 *}$ \\ ${ }^{1}$ Cairo University, Giza, Egypt \\ ${ }^{2}$ British University, Cairo, Egypt
}

\author{
Index Terms \\ Corporate social responsibility \\ Community environment \\ Corporate governance \\ Employees
}

Received: 1 September 2016 Accepted: 11 November 2016 Published: 19 December 2016

\begin{abstract}
Previous research on Corporate Social Responsibility (CSR) has mainly focused on the companies operating in different industry fields. Yet, a limited number of research have investigated the CSR practices in the banking sector. Accordingly, this study attempts to add further knowledge to this domain by measuring and comparing the extent and quality of CSR practices and their components which are: Employees, Community, Environment, and Corporate governance at a larger geographical scale. Moreover, the relationship between institutional environment and CSR and its components will be empirically examined. Secondary data provided by the CSRHUB database is used for a sample of 231 banks operating in five different regions from 2012 to 2015. The findings reveal that the CSR practices are exercised at a large scale across both developing and developed countries. Interestingly, the developing countries, especially those considered advanced economies or those having well-established international business relations with other developed countries, seem to have a progressing banking system that provides CSR at the highest international levels. Accordingly, no significant difference has been reported between banks in such developing countries and their counterparts in other developed countries. On the contrary, regional settings have significantly impacted the CSR in total and on each component. These results provide valuable insights and implications to both practitioners and academia. The researchers suggest studying the CSR practices for banks operating in less advanced developing countries.
\end{abstract}

(C) 2016 The Author(s). Published by TAF Publishing.

\section{INTRODUCTION}

Nowadays, CSR reporting becomes an important communication tool that informs stakeholders about economic, social and environmental practices of institutions. It has been expressed in literature that CSR is instrumental to institutions' legitimacy (Suchman, 1995; Aguilera, Rupp, Williams \& Ganapathi, 2007; Basu \& Palazzo, 2008; Claasen \& Roloff, 2012). Although banks are not involved in activities that pollute the environment, they might provide financial support to institutions that are involved in activities that harm the surroundings. Thus, banks are becoming increasingly aware that their clients' environmental and so- cial risks may in turn weaken their own business as lenders ( Kim, Kim \& Lee, 2015). As a result, banks try to avoid lending that may expose them to environmental risk and are developing CSR programs, policies and management systems to reduce such risks that can impair the bank profitability (Golob \& Bartlett, 2007; KPMG, 2013). Other factors that force banks to become more socially responsible are the increasing numbers of stakeholders that are looking at both financial and social performance from one side and the pressure exerted from the governments and policy makers for banks to become more socially responsible from the other side. According to International Institute

\footnotetext{
${ }^{*}$ Corresponding author: Wafaa Salah

${ }^{\dagger}$ Email: Wafaa.Salah@bue.edu.eg
} 
of Sustainable Development 2016 the integration of social and environmental activities into the banking sector takes two directions. The first direction is the banks' operations to include environmental initiatives as recycling programs and socially responsible initiatives as charitable donations. The second one is the integration of environmental and social activities into the banks' core businesses as strategies, mission and product design. For example, integrating the environmental and social criteria into lending and investment strategy.

Implementing CSR activities is not only essential to the business survival but also communicating CSR activities to the surrounding society generates many benefits as well. For instance, Herremans, Akathaporn \& McInnes (1993) found that U.S. manufacturing institutions with strong social reputation outperform poor social reputation institutions which lead to lower customer risk and better stock returns. Moreover, Marom (2006) mentions that socially responsible institutions enhance their own financial performance and sustainability, increase customers' satisfaction and loyalty, attract skilled employees and improve access to financial markets. A survey conducted by KPMG (2013) reveals that global institutions engaged in CSR reporting have an opportunity to increase their financial performance and obtain a competitive advantage. Deutsch \& Pintér (2014) argue that communicating CSR activities reduces operational risks and cost, controls the possible dispute and fixes the relationship with stakeholders. The more institutions affect the society positively, the more customers will have a positive perception of the company and its products and services, which in turn could lead to increasing the company's profits ( Kim et al. 2015).

According to Ofori \& Nyuur (2014), the African and Middle East regions particularly still need further research in this respect. Besides, the Asian banks were severely affected in 1997/1998 by financial systems crisis and similarly American banks were also affected in 2008 ( Bouvain, Baumann \& Lundmark, 2013). This makes USA and Asia considered to be important regions to be studied. Additionally, limited research has empirically investigated the CSR practices in the global banking sector (Rizkallah \& Martínez, 2011; Hetze \& Winistörfer, 2016). Likewise, Grabinski, Kedzior \& Krasodomska (2015) denotes that the CSR concept is commonly used in the scientific publications. Nevertheless, social responsibility in the banking industry is not a very popular field of study in Poland. Therefore, more CSR research is needed to provide better knowledge and new insights about CSR practices specially in the banking sec- tor ( Fukukawa, Shafer \& Lee, 2007; Cummings, 2008). Accordingly, this research seeks to attain two main objectives. First, to examine the CSR practices by banks in different regional settings. Second, to examine the effect of the developing status of a country on the extent and quality of such practices. To achieve these objectives, the researchers collected CSR secondary data provided by CSRHUB database. This database provides a comprehensive set of CSR data covering many regions and a large number of countries. It is also considered as one of the world's largest CSR ratings databases and adheres to the Global Reporting Initiative (GRI) guidelines (Aggarwal, 2013). The GRI is considered to be the most widely acknowledged standard on non-financial reporting worldwide (Skouloudis, Evangelinos \& Kourmousis, 2009). By default, the CSRHUB database provides unweighted score for CSR as well as for its components; community, employee, environment, and corporate governance. However, it allows for assigning weights if necessary. In this research, we keep all the collected CSR data unweighted.

The empirical findings show that banks operating in different regions tend to provide different CSR practices in terms of extent and quality. This has been mainly attributed to the influence of the institutional environment. For instance, Banks operating in North America and Europe tend to provide a higher quality of CSR disclosure practices in total and for each separate component. North America and Europe regions used to have well-established CSR legal environment. Other institutions such as financial institutions guidelines and labor unions have also contributed in raising the demand for the CSR disclosure by banks in such regions. Interestingly, the researchers spotted some progress in the CSR disclosure among the developing countries. Banks in Africa, Middle East and some Asian countries which accommodate most of the developing countries attained relatively high disclosure scores.

As a result, the differences in the CSR level and its components are not that significant. Despite the limited growth of the CSR practices across the developing countries especially in Africa, banks operating in advanced economies such as South Africa, United Arab Emirates, India and China provided higher quality CSR practices comparable to their counterparts in the other developing countries. Generally, more improvements are still needed, especially for the environment component. The rest of this paper is organized as follows: Section 2 elaborates the theoretical framework adopted in this study. Section 3 presents hypotheses development. Section 4 presents the research method used in 
this study. Then section 5 presents the results and finally the conclusions.

\section{LITERAT URE REVIEW}

There is no universal agreement on the definition of CSR or its main components. Each stakeholder such as borrowers, depositors, owners, governments, policy makers, employees, etc. defines CSR differently which is often biased toward particular expectations that each of these stakeholders brings to their relationship with institutions and so prevents the development and implementations of a unified concept (Van Marrewijk, 2003). From the stakeholders' perspective, CSR is defined as the response to stakeholders' needs (Basu \& Palazzo, 2008). The World Business Council on Sustainable Development (WBCSD) has defined CSR as the method in which institution contributes to a sustainable economic development of business, employees and society as a whole. Islam, Ahmed \& Hasan (2012) view CSR simply as the consideration given by banks to the impact of their operations on society.

Soh, Kim \& Whang (2014) point that the definition of CSR is compatible with the stakeholder theory, which assumes that institutions must be accountable to all stakeholders within a society. Review of existing literature on CSR shows that academics have not yet reached a general agreement on a unified framework for CSR reporting. Carroll (1979) develops the notion of CSR by adding a multidimensionality to CSR: economic, ethical, discretionary and legal. These dimensions were used in the literature but criticized for lacking the guidelines that help corporations in applying it. Elkington (1994) added to Carroll's CSR model, the environmental and sociocultural dimensions and removed the legal dimension due to his belief that CSR is a voluntary disclosure. Kanji \& Chopra (2010) added the social investment and economic responsibility dimensions due to their belief that previous CSR dimensions developed fail to identify social responsibility factors. Meanwhile, the Compact (2013) United Nations Global has developed CSR index that contains labor, anti-corruption, human rights and environment principles.

Banks play important financing and developing roles in the community which is essential to sustainable development (Levine, 2005; Beck, Demirgüç-Kunt \& Levine, 2010; Scholtens, 2011). Pérez \& Del Bosque (2012) mention that social banking institutions should provide a variety of legal, economic, ethical and discretionary services and hence their CSR practices and disclosure should be taken seriously. Since the global financial crisis in 2008, central banks worldwide try to strengthen the relationship be- tween banks and their clients. They try to encourage banks to become more socially responsible through establishing CSR strategies and activities (Deutsch \& Pintér, 2014). Central banks started to explore how to incorporate ethical coordination in public awareness and thus better satisfying social needs (Lentner, Szegedi \& Tatay, 2015). The Centre for the Study of Financial Innovation (CSFI) conducted a survey in 2012 that showed that banks' managers around the world are becoming more concerned about new regulations leading to increased transparency about banking operations (Lascelles, 2012). Vigano \& Nicolai (2009) mention that the banking sector has been quite slow in implementing CSR despite their intermediary role in the economy that exposes them to risk. Banks introduce environmental issues firstly then social issues. Similarly, Hetze \& Winistörfer (2016) mention that the banking sector reaction to CSR issues was slower than other more polluting industries. Weber, Diaz \& Schwegler (2014) analyzed how the financial sector performs with respect to CSR and make a comparison between the financial sector and other sectors. The empirical investigation reveals that financial sector performance is relatively low regarding CSR in general.

\section{CSR from Institutional Theory Perspective}

Most of CSR research has mainly examined CSR disclosure practices from agency theory (McWilliams \& Siegel, 2001), signaling theory, stakeholder theory (Donaldson \& Preston, 1995) and legitimacy theory (Guthrie \& Parker, 1989). These studies have also highlighted the implicit impact of the institutional environment on the implemented CSR practices and disclosure. Scholtens (2009), for instance announces that in the Organization for Economic Co-operation and Development (OECD) countries, specialized banks offer savings accounts to the public and promise to direct the collected savings in financing friendly environmental projects or in supporting new entrepreneurs who cannot access funds from normal financial institutions. Regarding the CSR disclosure, it has been recognized that in Denmark, most of the imposed pressures on the banks are exerted by the government, which is not true for Greece and Hungary.

Yet, in Hungary, the government is engaged by imposing the implementation of certain laws, such as those regarding equal opportunities or environmental protection (Metaxas \& Tsavdaridou, 2010). Similarly, Soh, Kim \& Whang (2014) suggest several reasons interpreting the disparity of CSR reporting practices between Western countries represented by USA and UK and Asian-Pacific countries. First, the power 
of law in the Western countries enables to create a welldeveloped form of governance. Secondly, the longer experience enables companies in Western countries to put more emphasis on non-financial activities. Thirdly, Western countries consider social activities as the main feature of a developed nation. This perception makes them keener about the CSR practices and their accountability. More reasons such as the power of civil societies and economic conditions are also believed to raise the importance of CSR in the Western countries.

In the same vein, Young \& Thyil (2014) argue that the institutional field shapes the implemented CSR practices. They clarify that the surrounded institutional field has several internal and external players that generate a positive or a negative influence on the CSR practices such as industrial associations, institutional investors, labor unions, consumers, media, and the government are equally important determinants of CSR activity of an organization. Another study has been conducted in Italy investigating the impact of the institutional investors especially if they are characterized as non-profit oriented investors on the quality of the CSR by banks. It is argued that institutional investors with a long-term perspective like pension funds and insurance companies are more likely to exert influence over managerial decisions regarding social, environmental and ethical issues. The researchers studied the case of MPS Bank, which is the oldest bank in Italy and found that this bank has been distinguished for a higher quality CSR practices and disclosure. They attributed this exceptional behavior to the efforts of its major institutional investor which has put more emphasis on the bank's social and environmental issues (Nicola \& Barbara, 2013). Accordingly, we argue that the institutional environment including all different types of institutions; culture, rituals, laws, norms, regulation and all alike could influence the CSR disclosure practices in banks. In this research, two levels of external institutional environments will be examined. The first level represents the geographical regions and the second level represents the developing status. The first level enables to spot the differences in CSR disclosure by banks operating in multiple regions and the second level considers the macroeconomic factor by examining and comparing the CSR disclosure by banks that operate in the developed economies with those operating in the developing economies.

\section{Hypothesis Development}

Based on the previous arguments, the researchers will investigate the impact of the institutional environment at the two previously mentioned levels by developing the following hypotheses.

\section{The Impact of Geographic Region on the CSR Disclosure}

Some geographical regions share similar institutional pressures that have a profound effect on the countries located within their boundaries. Consequently, it is expected that the CSR implemented by the banks in such regions will be affected. Doh \& Guay (2006) find that different institutional structures and political legacies in both US and the European Union are important factors in explaining how governments, NGOs, and the broader polity determine and implement CSR. Similarly, Golob \& Bartlett (2007) compare the CSR guidelines and reporting standards in both Australia and Slovenia. They find that in both countries, CSR reporting is largely voluntary.

However, CSR reporting in Australia is driven by product, management and financial considerations while Slovenian reporting is driven by employee, community and environmental concerns. They conclude that it is important to increase incentives in both countries to disclose CSR and to compare them to the global reporting requirements. Kuada \& Hinson (2012) conducted a comparative study to investigate the main reasons for adopting CSR practices in both local and foreign institutions operating in Ghana. A survey is conducted on the top 80 institutions in Ghana. The results show that foreign institutions are motivated by legal instructions, while local institutions are motivated mostly by discretionary and social considerations. Metaxas \& Tsavdaridou (2010) analyzed CSR activities in three European countries: Greece; Denmark; and Hungary. The objective was to trace the important elements needed for a successful CSR strategy. It was concluded that the effective implementation of CSR strategy cannot follow rigid and specific rules and should be adjusted to the differences in culture and individual needs of each country.

Weber et al. (2014) have also compared CSR performance but for other three different regions; North American, Europe and Asia-Pacific. They have examined several CSR-related aspects such as business ethics and product responsibility, labor issues, environmental performance, community issues, and corporate governance. The researchers have observed some regional differences whereby North America performed better than its counterparts in Europe and Asia-Pacific in terms of business ethics, corporate governance and product responsibility. Nevertheless, European institutions have performed better regarding the environment and labor issues. Likewise, Soh, Kim \& Whang (2014) found that U.K. tends to adopt the 
top-down approach whereas the U.S. adopts a bottom-

up approach towards CSR. This has resulted in raising the quality of the CSR reporting practices of the UK compared to USA as these practices have been imposed and monitored by the government. It is evident that some regions have more powerful institutions than others. Accordingly, we can hypothesize that:

H1: There is a relationship between geographical regions and the quality of CSR in total and its components; community, employees, environment and corporate governance.

\section{The Impact of the Developing Status}

Many developing countries suffer from several economic, social and political problems, hence it is arguable that the regulatory system in such countries may not be mature enough to govern the CSR disclosure by banking sector. This argument is consistent with the findings of Khan, Halabi \& Samy (2009) who investigated 20 banks operating in Bangladesh and found that only 50 percent of them report social matters in the chair's statement/directors' report. Meanwhile, 15 banks only disclosed such information in the notes to the accounts section.

The researchers have also recognized that no single bank attempts to disclose social and environmental information in a separate section. Moreover, the disclosed social and environmental data by these banks were not convincing from the users' point of view. Jain, Keneley \& Thomson (2015) argue that cultural differences, socio-economic and political climate are among the main factors underpinning the discrepancy in CSR reporting. On the other hand, Bihari \& Pradhan (2011) revealed that banks in India have improved their CSR activities, which positively affected their performance, image and goodwill. Likewise, Kaur \& Bhaskaran (2015) reported that the 2007 guidelines of RBI in India advised all scheduled commercial banks to make non-financial disclosure of their CSR practices. As a result, they found that all the investigated 20 banks have already provided non-financial disclosure. Moreover, a part of them has provided financial disclosure for their CSR practices. Ullah \& Rahman (2015) studied the nature and extent of CSR disclosed in the annual reports of 30 commercial banks in Dhaka Stock Exchange in Bangladesh. They have also examined the impact of bank characteristics and regulatory change on the CSR disclosure. The results reveal a satisfactory level of CSR disclosure by all listed commercial banks in Bangladesh. The volume and nature of CSR disclosed were affected by regulatory changes during 2008-2010. While, no significant relationship was found between CSR disclosure and bank attributes. Bhattacharyya \& Cummings (2014) examine the corporate managers' attitude towards environmental responsibility in two countries; Australia and India.

The results show positive attitudes toward environmental responsibility on both sides. However, Indian corporate managers were stronger in their support and have selected certain issues to be more important. Based on the above argument, the literature still provides no inconclusive results and thus it is hypothesized that:

H2: There is a relationship between the country developing status and the quality of CSR and its components; community, employees, environment and corporate governance.

\section{RESEARCH METHODOLOGY}

\section{Sample Size}

As explained earlier, the objective of this research is to investigate the institutional environment effect on the CSR disclosure and its components by banks at different institutional levels. Table 1 presents the data collected for 231 banks distributed over five main regions; North American (55) banks, European (72) banks, Asian (76) banks, Middle Eastern (18) banks and African (10) banks categorized into developing and developed countries.

TABLE 1. Sample distribution criteria

\begin{tabular}{lcccccc}
\hline \hline Country & Africa & Asia & Middle East & North America & Europe & Total \\
\hline Sample & $\mathrm{N}$ & $\mathrm{N}$ & $\mathrm{N}$ & $\mathrm{N}$ & $\mathrm{N}$ & $\mathrm{N}$ \\
Developing & 10 & 49 & 18 & 2 & 17 & 96 \\
Developed & $\mathrm{O}$ & 27 & $\mathrm{O}$ & 53 & 55 & 135 \\
Totals & 10 & 76 & 18 & 55 & 72 & 231 \\
\hline \hline Note: Asia includes three sub-regions; South East (18) countries, Indian (11) countries and other Asian countries (47)
\end{tabular}

These regions cover 46 different countries. The data have been collected for four years from 2012 to 2015 . In this study, we will be focusing solely on studying the CSR practices by banks since this area is still under research. The researchers have used the CSRHub database in collecting the CSR total score and its components; community, 
employees, environment and corporate governance. The data cover the main CSR disclosure indicesonly. However, the items that make up each of the CSR components have not been collected to avoid complexity given a large number of the studied banks.

\section{Data Collection and Analysis}

CSRHub dashboard provides monthly and annual data. Accordingly, the researchers calculated the average scores for every 12 months and for the four years collectively to reach an overall score. This has been systematically applied to the CSR total score and to each component ending up with 11088 (Year-bank) observations. Originally, data were collected for 358 Banks operating in the abovementioned regions. Yet, the final sample size was reduced to 231 banks after eliminating those having partial disclosure for the four studied years. The researchers have conducted a descriptive and explanatory study using ANOVA and MANOVA processed via IBM SPSS version 21 to test the research hypotheses.

\section{Explanatory Variables \\ The dependent variables}

In this research, five dependent variables have been studied and they are the total csr score and its four components; community score, employees score, environment score and corporate governance score. The CSR and its components' scores have been calculated and provided by the CSR Hub database. The total CSR score and even of its components are calculated as a percentage from $(0-100)$. The higher the percentage, the higher the quality of CSR disclosure. When the CSR disclosure score is high, this indicates that the bank has provided most of the required items as required by GRI.

\section{The independent variables}

In the light of the research hypotheses, two independent variables are identified. The first independent variable represents the geographical region (X1) that the bank is operating in and has been assigned a number from (1-5) in the following order. The researchers followed the geographic classification used by the CSRHub database as follows:

$\mathrm{X} 11$ = Africa

$\mathrm{X} 12$ = Asia (Asia, India and Southeast)

$\mathrm{X} 13$ = Europe

$\mathrm{X} 14=$ Middle East

X15 = North America (USA, Canada, Mexico)

The second independent variable (X2) measures the developing status of the country and has been measured as dichotomous variables (1) developed country, (0) developing country. The classification of the developing and developed countries is based on the United Nations' recent classification in November 2013. Accordingly, the following regression models will be processed:

(1)CSR $R_{i t}$ score $(Y 1)=\beta_{0}+\beta_{1}+X 1+\beta_{2} X 2+\epsilon_{i t}$

(2) Community $_{i t} \operatorname{score}(Y 2)=\beta_{0}+\beta_{1}+X 1+\beta_{2} X 2+\epsilon_{i t}$

(3)Employees ${ }_{i t}$ Score $(Y 3)=\beta_{0}+\beta_{1}+X 1+\beta_{2} X 2+\epsilon_{i t}$

(4)Environment ${ }_{i t}$ score $(Y 4)=\beta_{0}+\beta_{1}+X 1+\beta_{2} X 2+\epsilon_{i t}$

(5)CorporateGovernance ${ }_{i t}$ score $_{(Y 5)}=\beta_{0}+\beta_{1}+X 1+$ $\beta_{2} X 2+\epsilon_{i t}$

Whereby:

i: firm (banks)

t: Year (2012-2014)

$\beta_{0}$ : Constant

$\mathrm{X} 1$ : Geographic regions (takes the value from 1 to 5 )

$\mathrm{X} 2$ : Developing status takes dichotomous values (0) developing countries and (1) developed countries

$\epsilon_{i t}$ : Error

\section{RESULTS}

\section{The Descriptive Results}

The quality of CSR disclosure and its components has been classified into four progressing levels; advanced level, moderate level, poor level and lagging behind level as shown in the table 2. Table 2 describes the relative frequency for the different progressing levels of the CSR disclosure and its components for the selected sample (231 banks). Initially, it is observed that CSR has a small number of banks at an advanced level. In addition, the employees and community scores are having the largest number of banks at the advanced level. Meanwhile, the environment score has only one bank at the advanced level. This indicates that the environmental disclosure still needs more improvements by the banking sector. Table 2 also demonstrates that $60 \%$ of the banks achieve moderate level of CSR disclosures and very few banks (8\%) with an advanced level of CSR discourse headed by two USA banks which are Trustmark Corporation and Provident Financial Holdings, Inc. and the third advanced bank is the National Bank of Abu Dhabi. It has also been realized that relatively a large number of banks (74) representing 32 percent of the investigated banks have embraced poor CSR disclosures as they miss more than $60 \%$ of the required items. Unlike our earlier expectation, the banks that have been spotted with poor CSR performance belong to both developing and developed countries such as Singapore, Canada, Japan, India, Greece and Mexico. This implies that the banking industry in the developing 
countries is following close CSR disclosure pattern as that followed in the developed countries. This will be confirmed further by looking at the ANOVA results. To verify this result, the researchers have further analyzed this pattern for the main four components constituting the CSR practices. In general, a larger number of banks achieve a higher level of disclosure in respect of employees (187) banks followed by community (180) banks and finally corporate governance (129) banks compared with environment (10) banks.

TABLE 2 . Descriptive results of the CSR main index and the sub-indices of its components

\begin{tabular}{|c|c|c|c|c|c|c|c|c|c|c|}
\hline Banks (N) & Y1 & $\%$ & Y2 & $\%$ & Y3 & $\%$ & Y4 & $\%$ & Y5 & $\%$ \\
\hline $\begin{array}{l}\mathrm{N}>=60 \% \\
\text { (Advanced) }\end{array}$ & 19 & $8 \%$ & 38 & $16 \%$ & 76 & $33 \%$ & 1 & $0 \%$ & 19 & $8 \%$ \\
\hline $\begin{array}{l}\mathrm{N}=50-59 \% \\
\text { (Moderate) }\end{array}$ & 139 & $60 \%$ & 142 & $61 \%$ & 111 & $48 \%$ & 9 & $4 \%$ & 110 & $48 \%$ \\
\hline $\begin{array}{l}\mathrm{N}=40 \%-49 \% \\
\text { (poor) }\end{array}$ & 69 & $30 \%$ & 48 & $21 \%$ & 28 & $12 \%$ & 142 & $61 \%$ & 86 & $37 \%$ \\
\hline $\begin{array}{l}\mathrm{N}<40 \% \\
\text { (lagging) }\end{array}$ & 4 & $2 \% 3$ & $1 \%$ & 16 & $7 \%$ & 79 & $34 \%$ & 16 & $7 \%$ & \\
\hline Total & 231 & $100 \%$ & 231 & $100 \%$ & 231 & $100 \%$ & 231 & $100 \%$ & 231 & $100 \%$ \\
\hline
\end{tabular}

Investigating the CSR Disclosure Practices by Geographic Region

Table 3 shows that on average all the investigated regions provide a close but moderate level of CSR except for Asia (48\%). This is consistent with Weber et al. (2014) who studied the CSR in the financial sector and reported that financial sector performance is relatively low regarding CSR in general. Also, the banks with the highest disclosure level (more than 60\%) are found in North America, Europe and Middle East. Nevertheless, the highest deviation in the CSR by banks can be realized in Europe which covers 72 banks. Further analysis has been conducted to measure the changes in the CSR total score across the period from 2012 to 2015 by considering the year 2012 as a basic year. It is realized that many developing countries have witnessed a great improvement in the CSR disclosure over the time horizon. More interestingly, some developed countries such as USA, UK and Netherland has slight or no change at all during the last four years. This may imply that the CSR in such developed countries has reached its maturity level. This has been reflected in the table 3 when looking at the Maximum score column.

TABLE 3 . The descriptive results of the CSR disclosure index (\%)

\begin{tabular}{lcccccc}
\hline \hline Region & Mean & Median & MAX & MIN & SD & N \\
\hline Africa(X11) & 56 & 57 & 62 & 48 & 5 & 10 \\
Asia(X12) & 48 & 50 & 58 & 40 & 5 & 76 \\
Europe(X13) & 52 & 53 & 64 & 29 & 6 & 72 \\
Middle East(X14) & 55 & 55 & 64 & 43 & 4 & 18 \\
North America(X15) & 54 & 54 & 65 & 41 & 5 & 55 \\
Total Banks(N) & & & & & & 231 \\
\hline \hline
\end{tabular}

From the developing status respect, it can be realized that the developing and developed countries provided on average very close scores for the total CSR disclosure and for each component individually. However, it can be recognized that the variation among the developed countries is higher than among the developing countries as shown in table 4.
This may be attributed to the variations in the legal system developed in these countries. The lack of well-established legal system in many of the developing countries may encourage them to follow the most followed best practices and this has reduced the variations. 
TABLE 4 . The CSR descriptive results based on the developing status

\begin{tabular}{lllllllllll}
\hline \hline & \multicolumn{4}{c}{ Developing Countries } & \multicolumn{4}{c}{ Developed Countries } \\
\hline & Mean & Median & MAX & MIN & SD & Mean & Median & MAX & MIN & SD \\
CSR & 52 & 53 & 64 & 39 & 5 & 51 & 51 & 65 & 29 & 6 \\
Community & 55 & 56 & 64 & 41 & 5 & 54 & 54 & 69 & 32 & 7 \\
Employees & 56 & 56 & 70 & 38 & 6 & 55 & 56 & 82 & 29 & 11 \\
Environment & 49 & 50 & 66 & 35 & 6 & 51 & 51 & 72 & 36 & 7 \\
Corporate Governance & 50 & 49 & 63 & 36 & 6 & 51 & 51 & 65 & 29 & 7 \\
\hline \hline
\end{tabular}

\section{Community Disclosure Index}

In respect of the community disclosure by banks, table 5 demonstrates that there is a great attention paid to this type of disclosure as banks reached the highest levels in most of the regions especially in North American and Europe. However, other regions such as Africa, Middle East and Asia reached very close levels with lower variation as indicated by the standard variation results. It is also shown that on average banks' community disclosure is very close to a regional level whereby Africa (58\%) and North America (56\%). Yet, North America and Europe have the same highest disclosure level (69\%). This was expected as these two regions contain most of the developed countries which have more established community laws and regulation. In respect of the variation, again Europe has the highest standard variation for this index as it is shown for the total CSR as well. This may imply that the institutional environments across European countries are obviously different.

TABLE 5. The descriptive results of the community disclosure index (\%)

\begin{tabular}{lcccccc}
\hline \hline Region & Mean & Median & MAX & MIN & SD & N \\
\hline Africa(X11) & 58 & 58 & 62 & 49 & 4 & 10 \\
Asia(X12) & 53 & 54 & 63 & 42 & 5 & 76 \\
Europe(X13) & 54 & 56 & 69 & 32 & 8 & 72 \\
Middle East(X14) & 55 & 55 & 64 & 43 & 4 & 18 \\
North America(X15) & 56 & 55 & 69 & 48 & 5 & 55 \\
Total Banks(N) & & & & & & 231 \\
\hline \hline
\end{tabular}

\section{Employees' Disclosure Index}

Disclosure of the employees' related issues has become one of the key disclosure items that many companies including banks put more emphasis on. It can be realized that in general, the employees' index provides better results compared with the last two indices as shown in table 6. On average,
Europe (60\%) followed by Africa (59\%) attained the highest scores. Meanwhile, the highest maximum scores were reported in Europe (82\%), North America (73\%) and Africa (70\%). The highest variation has also been realized in Europe as the case in the previous indices.

TABLE 6 . The descriptive results of the employees' disclosure index (\%)

\begin{tabular}{lcccccc}
\hline \hline Region & Mean & Median & Maximum & Minimum & SD & N \\
\hline Africa(X11) & 59 & 61 & 70 & 44 & 9 & 10 \\
Asia(X12) & 51 & 54 & 68 & 36 & 8 & 76 \\
Europe(X13) & 60 & 62 & 82 & 29 & 11 & 72 \\
Middle East(X14) & 55 & 55 & 67 & 43 & 6 & 18 \\
North America(X15) & 57 & 56 & 73 & 47 & 6 & 55 \\
Total Banks(N) & & & & & & 231 \\
\hline \hline
\end{tabular}




\section{Environment Disclosure Index}

Environment disclosure has become one of the key voluntary disclosure items for many banks. Nevertheless, it seems not the case for the banking sector. The environmental scores are relatively lower than the other three types of disclosures in some regions such as Middle East (49\%) and Asia (48\%). Meanwhile, North America (50\%), Europe
$(52 \%)$ and Africa (52\%) attain a moderate level. The maximum scores have been reported for Europe (72\%) followed by Middle East (66\%) and North America (61\%). Again the highest variation is spotted in Europe and the Middle East as well. This could be regarded to the fact that banks perceive themselves as non-polluting industry as explained in the introduction.

TABLE 7. The descriptive results of the Environment disclosure index (\%)

\begin{tabular}{lcccccc}
\hline \hline Region & Mean & Median & Maximum & Minimum & SD & N \\
\hline Africa(X11) & 52 & 52 & 57 & 49 & 3 & 10 \\
Asia(X12) & 48 & 48 & 59 & 37 & 5 & 76 \\
Europe(X13) & 52 & 53 & 72 & 36 & 7 & 72 \\
Middle East(X14) & 49 & 50 & 66 & 35 & 7 & 18 \\
North America(X15) & 50 & 51 & 61 & 37 & 6 & 55 \\
Total Banks(N) & & & & & & 231 \\
\hline \hline
\end{tabular}

\section{Corporate Governance Disclosure Index}

Corporate governance is an essential part of the voluntary disclosure that many companies including banks used to disclose on a regular basis. Table 8 demonstrates the descriptive results for this component. It can be realized that on average Africa (54\%) and North America (54\%) lead the other regions in respect of the corporate governance dis- closure. However, North America achieved the highest disclosure level (65\%) followed by Europe (64\%) then Middle East (63\%) and Africa (63\%). It can also be realized that the variations between African countries are higher than those of the countries in the other regions. This may be partially due to the lack of well-established regulations that govern the corporate governance disclosure in these countries.

TABLE 8 . The descriptive results of the corporate governance disclosure index (\%)

\begin{tabular}{lcccccc}
\hline \hline Region & Mean & Median & Maximum & Minimum & SD & Total N \\
\hline Africa(X11) & 54 & 56 & 63 & 42 & 8 & 10 \\
Asia(X12) & 46 & 46 & 59 & 36 & 6 & 76 \\
Europe(X13) & 52 & 53 & 64 & 29 & 6 & 72 \\
Middle East(X14) & 51 & 49 & 63 & 41 & 6 & 18 \\
North America(X15) & 54 & 54 & 65 & 41 & 5 & 55 \\
Total Banks(N) & & & & & & 231 \\
\hline \hline
\end{tabular}

\section{The Explanatory Results}

As demonstrated earlier, this research pursues to address two hypotheses. The first one investigates the association between the geographic regions and the CSR disclosure practices which are implemented by banks. Accordingly, it is assumed that banks operating within the same region are more inclined to exercise similar disclosure pattern. On the other hand, banks operating in different regions might be affected by different cultures and regulative environment as indicated by the previous CSR-related research. These institutional pressures may give them unique features. This has been tested by conducting One Way ANOVA to investi- gate whether banks operating in different regions have significantly different CSR practices. Table 9 demonstrates that region has a significant effect on the total CSR disclosure level and its components at $(\mathrm{p}<0.01)$ except for the community disclosure index which shows a significant effect but at $(p<10)$. F- Statistics have also demonstrated this significant relationship. This result is consistent with Sun, Wang, Wang \& Yin (2015) who investigated the CSR practices by banks in China and found that banks are more inclined to report CSR if they operate in communities where more companies publish CSR reports or if there are guidelines encouraging CSR reporting. 
TABLE 9. The impact of geographic regions on the CSR disclosure and its components

\begin{tabular}{|c|c|c|c|c|c|c|}
\hline Disclosure Indices & Source & Sum of Squares & df & Mean Square & $\mathbf{F}$ & $P$-value \\
\hline \multirow[t]{3}{*}{ CSR index } & Between Groups & 903.437 & 4 & 225.859 & 7.373 & 0.000 \\
\hline & Within Groups & 6923.402 & 226 & 30.635 & & \\
\hline & Total & 7826.840 & 230 & & & \\
\hline \multirow[t]{3}{*}{ Community index } & Between Groups & 340.498 & 4 & 85.124 & 2.399 & 0.051 \\
\hline & Within Groups & 8017.918 & 22635.478 & & & \\
\hline & Total & 8358.416 & 230 & & & \\
\hline \multirow[t]{3}{*}{ Employees' index } & Between Groups & 2632.267 & 4 & 658.067 & 9.017 & 0.000 \\
\hline & Within Groups & 16494.028 & 22672.982 & & & \\
\hline & Total & 19126.294 & 230 & & & \\
\hline \multirow[t]{3}{*}{ Environment index } & Between Groups & 722.346 & 4 & 180.586 & 4.840 & 0.001 \\
\hline & Within Groups & 8432.745 & 226 & 37.313 & & \\
\hline & Total & 9155.091 & 230 & & & \\
\hline \multirow[t]{3}{*}{ Corporate governance index } & Between Groups & 2005.392 & 4 & 501.348 & 13.235 & 0.000 \\
\hline & Within Groups & 8560.842 & 226 & 37.880 & & \\
\hline & Total & 10566.234 & 230 & & & \\
\hline
\end{tabular}

Table 10 demonstrates the ANOVA results for the second hypothesis which examines the relationship between the developing status of a country and the extent and quality of the CSR disclosure and its components. It is realized that the developing status of a country has no significant effect on the CSR disclosure practices and its components. This implies that the CSR disclosure in both developing and developed countries are relatively closer to each other. This may be attributed to the fact that the investigated developing countries are those having trading international relationships with other developed countries and hence their bank- ing systems are consistently developing to meet the needs of the international markets. Besides, most of the included developing countries such as India, China, UAE, Saudi Arabia, Qatar, Indonesia and Malaysia are advanced economies and considered as open markets for international business, the issue that enforces these countries to improve their banking systems to support their business's needs. Therefore, the results have been positively affected because of the existence of these countries and the absence of the less developed countries.

TABLE 10. The impact of the developing status on the CSR disclosure and its components

\begin{tabular}{|c|c|c|c|c|c|c|}
\hline & & Sum of Squares & df & Mean Square & $\mathbf{F}$ & $P$-value \\
\hline \multirow[t]{3}{*}{ 1. CSR index } & Between Groups & 52.025 & 1 & 52.025 & 1.532 & 0.217 \\
\hline & Within Groups & 7774.815 & 229 & 33.951 & & \\
\hline & Total & 7826.840 & 230 & & & \\
\hline \multirow[t]{3}{*}{ 2. Community Index } & Between Groups & 70.890 & 1 & 70.890 & 1.959 & 0.163 \\
\hline & Within Groups & 8287.526 & 229 & 36.190 & & \\
\hline & Total & 8358.416 & 230 & & & \\
\hline \multirow[t]{3}{*}{ 3. Employees' index } & Between Groups & 52.728 & 1 & 52.728 & .633 & 0.427 \\
\hline & Within Groups & 19073.567 & 229 & 83.291 & & \\
\hline & Total & 19126.294 & 230 & & & \\
\hline \multirow[t]{3}{*}{ 4. Environmental index } & Between Groups & 179.214 & 1 & 179.214 & 4.572 & 0.034 \\
\hline & Within Groups & 8975.877 & 229 & 39.196 & & \\
\hline & Total & 9155.091 & 230 & & & \\
\hline \multirow[t]{3}{*}{ 5. Corporate governance index } & Between Groups & 11.279 & 1 & 11.279 & .245 & 0.621 \\
\hline & Within Groups & 10554.954 & 229 & 46.092 & & \\
\hline & Total & 10566.234 & 230 & & & \\
\hline
\end{tabular}




\section{Robustness Test}

An additional test has been undertaken to ensure the robustness of our findings. Specially, we did not find a significant difference between developing and developed countries in respect of the CSR in general or its components except for the environmental disclosure. Accordingly, we further divided the developing countries into two sub-groups. The first group represents the developing countries that are adjacent to or located among the developed economies, namely, North America and Europe. The second represents the developing countries that are adjacent to or located among less developed economies like Africa, Asia and the Middle East. The MANOVA results are shown in table 11. The table shows that there is a significant positive relationship between the created independent variable (belonging to more developed economies) and the five dependent variables at a very high significant level $(p<0.001)$.

TABLE 11. The impact of the developed economies on the developing countries' CSR disclosure

\begin{tabular}{lccccc}
\hline \hline Dependent Variables & df & F & $\boldsymbol{P}$-value & Partial Eta Squared & Adjusted R Square \\
\hline CSR & 1 & 41.76 & .000 & 0.24 & 0.233 \\
Community & 1 & 14.76 & .000 & 0.10 & 0.093 \\
Employees & 1 & 69.54 & .000 & 0.34 & 0.338 \\
Environment & 1 & 10.58 & .001 & 0.07 & 0.067 \\
Corporate Governance & 1 & 94.69 & .000 & 0.42 & 0.411 \\
\hline \hline
\end{tabular}

Based on the above results, it is suggested that the institutional impact could be extended further to the nearby geographical area. Hence, it is expected to find some difference between the developing countries that share the boundaries or are close to more developed countries and these are surrounded by less developed countries. According to our empirical results, the following implications can be recognized. First, in the last four years, the world awareness of the importance of CSR disclosure in the banking sector has been gradually increasing. Secondly, it can be realized that banks especially in the developing countries have been consistently working on improving the quality of their social and environmental disclosure. The CSR literature reveals that some developing countries have already issued guidelines or regulations to organize this issue at a country level as in India's case (David \& Linne, 2016). Likewise, Jain et al. (2015) study reported that the number of banks in Asia-Pacific region including India, Japan, China which have annually reported at least 50 percent out of 60 CSR indicators has been doubled from 2005 to 2011. This is expected as a large number of banks in the developed countries have already reached mature level of CSR disclosure.

\section{DISCUSSION AND CONCLUSION}

This research has addressed the CSR practices by banks from the institutional perspective. In elaboration, it basically examines the impact of the macro institutional environment on the embraced CSR disclosure practices in different regions. The classic institutional theory postulates that the institutional environment leads to more con- vergent practices among the individuals and organizations operating within the same institutional environment. The empirical results of this research have relatively supported this argument and explicitly reveal that banks operating in different regions are more likely to implement different CSR practices. Even that the quality and progress level in such regions could be diverse. This could be attributed to the power of legal environment that imposes the regulations, rules or laws to enforce banks in such regions to improve their CSR disclosure level. It has been also realized that most of the banks worldwide tend to disclose more information about activities related to employees, the overall community in addition to corporate governance rather than environmental information. Yet, a number of banks have neither disclosed items related to the environment nor disclosed adequate information in this respect.

The researchers has also concluded that there is no great difference between developed and developing countries in respect of the CSR disclosure practices by banks. This is due to the fact that the investigated developing countries in this research are normally classified as advanced economies such as China, India, Egypt, United Arab Emirates, Qatar, Kuwait and South Africa. They are also having various financial and commercial international relationships with many developed countries which may directly and indirectly expose them to the international regulations organizing and controlling the CSR practices in the banking sector. Some countries such as India and South Africa pursue to improve their banking sector by raising the quality of the CSR practices. 


\section{LIMITATIONS AND IMPLICATIONS}

This research has several limitations that may restrict the generalizability of the generated results. First, banks with partial CSR disclosure or missing data in any of the studied years have been eliminated from the sample for consistency. As a result, a limited number of banks in some countries have been investigated. Secondly, banks operating in advanced developing economies such as Egypt, Qatar, India and United Arab Emirates showed high CSR disclosure level which is not necessary to be extended to other less advanced developing countries. Thirdly, the researchers have focused mainly on investigating the institutional impact on the CSR disclosure in the banking sector ignoring the banks' attributes. The researchers suggest studying the CSR practices for banks operating in less advanced developing countries.

\section{Acknowledgment}

Both authors contributed equally in this research paper but names are written in alphabetical order.

\section{REFERENCES}

Aggarwal, P. 2013. Impact of corporate governance on corporate financial performance. Journal of Business \& Manage- ment, 13(3): 01-05.

Aguilera, R.V., Rupp, D.E., Williams, C.A., \& Ganapathi, J. 2007. Putting the S back in corporate social responsibility: A multi- level theory of social change in organizations. Academy of Management Review, 32(3): 836-863.

DOI: 10.5465/AMR.2007.25275678

Basu, K., \& Palazzo, G. 2008. Corporate social responsibility: A process model of sense making. Academy of Management

Review, 33(1): 122-136. DOI: 10.5465/AMR.2008.27745504

Bouvain, P., Baumann, C., \& Lundmark, E. 2013. Corporate social responsibility in financial services: A comparison of Chi- $\quad$ nese and East Asian banks vis-à-vis American banks. International Journal of Bank Marketing, 31(6): 420-439.

DOI: 10.1108/IJBM-05-2012-0054

Beck, T., Demirgüç-Kunt, A., \& Levine, R. 2010. Financial institutions and markets across countries and over time: The up- dated financial development and structure database. The World Bank Economic Review, 24(1): 77-92.

DOI: $10.1093 /$ wber/lhp016

Bhattacharyya, A., \& Cummings, L. 2014. Attitudes towards environmental responsibility within Australia and India: A com- parative study. Journal of Environmental Planning \& Management, 57(5): 769-791.

DOI: $10.1080 / 09640568.2013 .768972$

Bihari, S.C., \& Pradhan, S. 2011. CSR and Performance: The story of banks in India. Journal of Transnational Management, 16(1): 20-35. DOI: 10.1080/15475778.2011.549807

Carroll, A.B. 1979. A three-dimensional conceptual model of corporate performance. Academy of Management Review, 4(4): 497-505. DOI: $10.2307 / 257850$

Claasen, C., \& Roloff, J. 2012. The link between responsibility and legitimacy: The case of De Beers in Namibia. Journal of Business Ethics, 107(3): 379-398. DOI: 10.1007/s10551-011-1045-0

Compact, U.G. 2013. Global corporate sustainability report 2013. UN Global Compact Reports, 5(1): 1-28.

DOI: $10.5848 /$ UNGC.5720.2014.0009

Cummings, L.S. 2008. Managerial attitudes toward environmental management within Australia, the People's Republic of

China and Indonesia. Business Strategy \& the Environment, 17(1): 16. D0I: 10.1002/bse.515

Deutsch, N., \& Pintér, E. 2014 . The link between corporate social performance and corporate financial performance

in the banking sector. Paper presented at the conference Recent Advances in Energy, Environment and Financial Science, Geneva, $\mathrm{CH}$.

Doh, J. P., \& Guay, T.R. 2006. Corporate social responsibility, public policy, and NGO activism in Europe and the United States: An institutional-stakeholder perspective. Journal of Management Studies, 43(1): 47-73.

DOI: $10.1111 / \mathrm{j} .1467-6486.2006 .00582 . \mathrm{x}$

Donaldson, T., \& Preston, L.E. 1995. The stakeholder theory of the corporation: Concepts, evidence, and implications. Academy of Management Review, 20(1): 65-91. D0I: 10.2307/258887

David, C., \& Linne, M.L. 2016. Introduction: Sustainability and social responsibility, in David Crowther, Linne Marie Lauesen

(Eds.), Accountability and social responsibility: International perspectives developments in corporate governance and responsibility, vol. 9. Bingley, UK: Emerald Group Publishing Limited. 
Elkington, J. 1994. Towards the sustainable corporation: Win-win-win business strategies for sustainable development. California Management Review, 36(2): 90-100. DOI: 10.2307/41165746

Fukukawa, K., Shafer, W.E., \& Lee, G.M. 2007. Values and attitudes toward social and environmental accountability: A study of MBA students. Journal of Business Ethics, 71(4): 381-394. DOI: 10.1007/s10551-005-3893-y

Golob, U., \& Bartlett, J.L. 2007. Communicating about corporate social responsibility: A comparative study of CSR reporting in Australia and Slovenia. Public Relations Review, 33(1): 1-9. D0I: 10.1016/j.pubrev.2006.11.001

Guthrie, J., \& Parker, L.D. 1989. Corporate social reporting: A rebuttal of legitimacy theory. Accounting \& Business Re- search, 19(76): 343-352. DOI: 10.1080/00014788.1989.9728863

Grabinski, K., Kedzior, M., \& Krasodomska, J. 2015. Blended learning in an accounting course-Polish students' perceptions. Accounting \& Management Information Systems, 14(2): 378-397.

Herremans, I.M., Akathaporn, P., \& McInnes, M. 1993. An investigation of corporate social responsibility reputation and eco- $\quad$ nomic performance. Accounting, Organizations \& Society, 18(7): 587-604. DOI: 10.1016/0361-3682(93)90044-7

Hetze, K., \& Winistörfer, H. (2016). CSR communication on corporate websites compared across continents. International Journal of Bank Marketing, 34(4), 501-528. D0I: 10.1108/IJBM-02-2015-0022

Islam, Z. M., Ahmed, S.U., \& Hasan, I. 2012. Corporate social responsibility and financial performance linkage: Evidence from the banking sector of Bangladesh. Journal of Organizational Management, 1(1): 14-21.

Jain, A., Keneley, M., \& Thomson, D. 2015. Voluntary CSR disclosure works! Evidence from Asia-Pacific banks. Social Re- $\quad$ sponsibility Journal, 11(1): 2-18. DOI: 10.1108/SRJ-10-2012-0136

Kanji, G.K., \& Chopra, P. K. 2010. Corporate social responsibility in a global economy. Total Quality Management, 21(2): 119-143. DOI: 10.1080/14783360903549808

Kaur, S., \& Bhaskaran, R. 2015. Corporate social responsibility disclosure practices of public and private sector banks in India: A comparative analysis. IUP Journal of Management Research, 14(2): 24-38.

Khan, H.U.Z., Halabi, A.K., \& Samy, M. 2009. Corporate social responsibility (CSR) reporting: A study of selected banking companies in Bangladesh. Social Responsibility Journal, 5(3): 344-357. DOI: 10.1108/17471110910977276

Kim, C., Kim, S.H., \& Lee, K.H. 2015. A comparison study of multinational chain hotel employees' perceptions of corporate social responsibility in China and Korea. Emerging Markets Finance \& Trade, 51(2): 364-376.

Kuada, J., \& Hinson, R.E. 2012. Corporate social responsibility (CSR) practices of foreign and local companies in Ghana.

Thunderbird International Business Review, 54(4): 521-536. DoI: 10.1002/tie.21481

DOI: $10.1080 / 1540496 X .2015 .1021599$

KPMG. 2013. Corporate sustainability: A progress report. KPMG International.

Lascelles, D. 2012. Banking banana skins 2012. The system in peril. Centre for the Study of Financial Innovation (CSFI).

New York, NY: Centre for the Study of Financial Innovation (CSFI).

Lentner, C., Szegedi, K., \& Tatay, T. 2015. Corporate social responsibility in the banking sector. Public Finance Quarterly, 1: $\quad 1-9$.

Levine, R. 2005. Finance and growth: Theory and evidence. Handbook of Economic Growth. In P. Aghion \& S. N. Durlauf

(Eds.), Handbook of economic growth, vol 1: 865-934. North Holland, NL: Elsevier.

Marom, I.Y. 2006. Toward a unified theory of the CSP-CFP link. Journal of Business Ethics, 67(2): 191-200.

DOI: $10.1007 / \mathrm{s} 10551-006-9023-7$

McWilliams, A., \& Siegel, D. 2001. Corporate social responsibility: A theory of the firm perspective. Academy of Manage- ment Review, 26(1): 117-127. DOI: 10.5465/AMR.2001.4011987

Metaxas, T., \& Tsavdaridou, M. 2010. Corporate social responsibility in europe: Denmark, Hungary and Greece. Journal of Contemporary European Studies, 18(1): 25-46. D0I: 10.1080/14782801003638679

Nicola, M. \& Barbara, M. 2013. Banking foundations and the CSR of Italian listed banks: The case of Monte dei Paschi di Siena. In S. Young \& S. Gates (Eds.), Institutional investors' power to change corporate behavior: International per- $\quad$ spectives (Critical studies on corporate responsibility, governance and sustainability), Vol 5: 225 - 251 . Bingley, UK: Emerald Group Publishing Limited.

Ofori, D.F., \& Nyuur, R.B. 2014. Corporate social responsibility and financial performance: Fact or fiction? A look at Ghana- 
ian banks. Acta Commercii, 14(1): 1-11. DOI: 10.4102/ac.v14i1.180

Pérez, A., \& Del Bosque, I.R. 2012. The role of CSR in the corporate identity of banking service providers. Journal of Business Ethics, 108(2): 145-166. DOI: 10.1007/s10551-011-1067-7

Rizkallah, É., \& Martínez, B.U.E.N.D.Í. A. 2011. Corporate social responsability in the financial sector: Are financial coopera- tives reddy to the challenge. Ciriec España, Revista de Economía Pública, Social y Cooperativa, 1(73): 127-149.

Scholtens, B. 2009. Corporate social responsibility in the international banking industry. Journal of Business Ethics, 86(2): 159-175. DOI: 10.1007/s10551-008-9841-x

Scholtens, B. 2011. Corporate social responsibility in the international insurance industry. Sustainable Development, 19(2): 143-156. DOI: $10.1002 /$ sd.513

Skouloudis, A., Evangelinos, K., \& Kourmousis, F. 2009. Development of an evaluation methodology for triple bottom line reports using international standards on reporting. Environmental Management, 44(2): 298-311.

DOI: $10.1007 / \mathrm{s} 00267-009-9305-9$

Soh, C., Kim, H.J., \& Whang, T. 2014. Corporate social responsibility (CSR) implementation in South Korea: Lessons from American and British CSR Policies. Journal of International \& Area Studies, 21(2): 99-118.

Suchman, M.C. 1995. Managing legitimacy: Strategic and institutional approaches. Academy of Management Review, 20(3): 571-610. DOI: 10.5465/AMR.1995.9508080331

Sun, J., Wang, F., Wang, F., \& Yin, H. 2015. Community institutions and initial diffusion of corporate social responsibility practices in China's banking industry. Management \& Organization Review, 11(03): 441-468.

DOI: $10.1017 /$ mor. 2015.31

Ullah, M.H., \& Rahman, M.A. 2015. Corporate social responsibility reporting practices in banking companies in Bangladesh: Impact of regulatory change. Journal of Financial Reporting \& Accounting, 13(2): 200-225.

DOI: $10.1108 / J F R A-05-2013-0038$

Van Marrewijk, M. 2003. Concepts and definitions of CSR and corporate sustainability: Between agency and communion. Journal of Business Ethics, 44(2-3): 95-105. DOI: 10.1023/A:1023331212247

Vigano, F. \& Nicolai, D. 2009. CSR in the european banking sector. Evidence from a survey. In: Barth, R. \& Wolff., F (Eds.) Corporate social responsibility in Europe: Rhetoric and realities. Cheltenham, UK: Edward Elgar Publishing Inc. DOI: $10.4337 / 9781848447233.00017$

Weber, O., Diaz, M., \& Schwegler, R. 2014. Corporate social responsibility of the financial sector-strengths, weaknesses and the impact on sustainable development. Sustainable Development, 22(5): 321-335. D0I: 10.1002/sd.1543

Young, S., \& Thyil, V. 2014. Corporate social responsibility and corporate governance: Role of context in international set- $\quad$ tings. Journal of Business Ethics, 122(1): 1-24. D0I: 10.1007/s10551-013-1745-8 